\section{Saving the trees, revitalizing your coffee table and shoring up the future}

$\mathrm{M}$

any of our readers know BioTechniques from the print edition that finds its way onto the coffee table every month. Lately, many of our readers will also have become aware of how our website has evolved, becoming a place to discover expert commentary and discussion, with thought-provoking Interviews, Opinion pieces, Podcasts and panel discussions examining the latest tools and techniques available to the lab researcher, in addition to our educational webinars and News section.

Both our online and print articles are free to read, and it is our intention to keep it that way. However, the publishing landscape is changing, and BioTechniques must, like our labs, continually evolve to keep up. That's why we have some changes coming in 2020.

First up, we are revitalizing our print edition. We care about the planet, and thus as of 2020 we will be consolidating our articles into quarterly print editions, helping us reduce our impact on the environment and save trees. This won't mean you lose out - we will be publishing the same (if not more!) content, but it will arrive on your coffee table with a refreshed feel - Reports and Benchmarks will remain alongside exciting editorial content such as our traditional Tech News, Interviews, Top Tips and other fascinating articles.

Second up, the way you use the website is changing. Going forward, readers will be able to access three articles a month before they are required to log-in with their (free) subscription - and I emphasize that that subscription will be free. Our peer-reviewed articles will remain open access, as they always have been.

In the rapidly changing landscape of scientific research and publishing, these changes will shore up the future for BioTechniques, allowing us to maintain our editorial excellence and continue to provide you, our reader, with free-to-access content. By continuing your subscription, you will help us continue to provide the latest in methods, tools and technical advances freely to researchers across the globe, regardless of where they are.

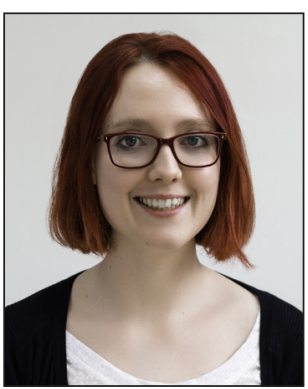

So please, continue to read and enjoy BioTechniques for free, for years to come, and email me if you have any queries regarding the above at flake@biotechniques.com.

\section{Francesca Lake}

Editor in Chief, Future Science Group, Unitec House, 2 Albert Place, London, UK. flake@biotechniques.com

BioTechniques is a peer-reviewed journal dedicated to the publication of original laboratory methods, related technical tools and methods-oriented review articles that are of broad interest to scientists engaged in basic applied life science research. Complete Instructions for Authors are available at: https://mc04.manuscriptcentral. com/fs-btn, BioTechniques' website for online manuscript submission. All manuscripts should be submitted at this site.

\section{BioTechniques Staff}

\section{Editorial, Production \& Circulation}

Chairman: James Drake

Managing Director. Phil Garner

Editor in Chief: Francesca Lake

Publisher. Sarah Mayes

Managing Editor. Joseph Martin

Digital Editor. Tristan Free

Head of Production: Zara Robinson

\section{Sales \& Business Offices}

Advertising: JT Hronich • jt@biotechniques.com

Subscriptions: Dominik March•d.march@future-science.com

Reprints: Sam Cavana •s.cavana@future-science.com

List Rental: Leela Ripton • I.ripton@future-science.com

Permissions: Adriana Gonzalez•a.gonzalez@future-science.com

\section{Editorial Board}

Bill Brizzard, Indiana University Research and

Technology Corp.

Bruce Budowle, UNT Health Science Center

Piotr Chomczynski, Molecular Research Center

Rita R. Colwell, University of Maryland-College Park and Johns Hopkins University

Joshua J. Coon, University of Wisconsin-Madison

David Cronk, Charles River Laboratories

Manel Esteller, Spanish National Cancer Centre (CNIO)

Jeffrey Felton, Western University of Health Sciences

Erica A. Golemis, Fox Chase Cancer Center

Peter M. Gresshoff, The University of Queensland

Yoshihide Hayashizaki, RIKEN

Jörg Hoheisel, German Cancer Research Center

Pui-Yan Kwok, University of California, San Francisco

Rachael L. Neve, Massachusetts Institute of Technology

Peter J. Oefner, University of Regensburg

Stephen W. Paddock, University of Wisconsin-Madison

Scott D. Patterson, Gilead Sciences, Inc.

Leonard F. Peruski, Jr., Centers for Disease Control

George Poste, Arizona State University

John Quackenbush, Harvard School of Public Health

Joshua Rappoport, Northwestern University School of

Medicine

John Rossi, City of Hope

Michel Goedert, MRC

Herbert P. Schweizer, Colorado State University

Barton Slatko, New England Biolabs

Steve S. Sommer, MEDomics, LLC

Igor Stagljar, University of Toronto

Mathias Uhlén, The Royal Institute of Technology

Timothy Veenstra, SAIC-Frederick, Inc.

Kent E. Vrana, Penn State College of Medicine

Michael Weiner, AxioMx 